\title{
Prensa, opinión y música teatral en Madrid, 1780-1791
}

\author{
Press, Opinion and Music Theatre \\ in Madrid, 1780-1791
}

A través del estudio de dos tonadillas escénicas y de artículos publicados en la prensa periódica madrileña, este trabajo sugiere que el teatro musical en Madrid constituyó un caldo de cultivo para la formación de la opinión pública moderna en España. Este fenómeno se observa de modo particular entre 1780 y 1791, año en que se prohibieron temporalmente las publicaciones periódicas. La reapertura del Teatro de los Caños del Peral en 1787 dio lugar a que los periódicos madrileños publicaran numerosos artículos y cartas debatiendo la posición del teatro extranjero frente al nacional. A raíz de este y otros debates similares, tanto prensa como tonadillas cuestionaron si el fenómeno de la opinión traía algún beneficio a la sociedad española. Como conclusión, se mostrará que la teoría de Jürgen Habermas sobre la esfera pública ilumina algunos aspectos, si bien no todos, de la génesis de la opinión pública en España. Por tanto, el hecho de que el caso español difiera de los considerados por Habermas no quiere decir España haya quedado al margen de los procesos de formación de la opinión pública moderna en Europa.

Palabras clave: teatro musical, tonadilla, prensa, opinión, Ilustración, Madrid.

Through the study of two stage tonadillas escénicas and articles published in the Madrid periodical press, this article suggests that music theatre in Madrid was a breeding ground for the formation of modern public opinion in Spain. This phenomenon can be especially observed between 1780 and 1791, the year when periodical publications were temporarily banned. The reopening of the Teatro de los Caños del Peral in 1787 led to the publication of numerous articles and letters debating the situation of foreign versus national theatre in the Madrid press. As a result of this and other similar debates, both the press and tonadillas questioned whether the phenomenon of opinion Spanish society. To conclude, I will argue that Jürgen Habermas's theorization of the public sphere only partially illuminates the genesis of modern public opinion in Spain. In the end, the fact that the Spanish case differs from those considered by Habermas doesn't mean that Spain has remained on the sidelines of the European processes of the formation of modern public opinion.

Keywords: theatre, tonadilla, press, opinion, Enlightenment, Madrid.

Este artículo tiene como objetivo estudiar las conexiones entre prensa, opinión y teatro musical para mostrar cómo los debates en torno al teatro musical en Madrid estimularon la formación de la opinión pública moderna en sus etapas iniciales. Como condición previa al establecimiento de una opinión pública, fue necesario definir quiénes tenían derecho a opinar y bajo qué condiciones. Las discusiones sobre el derecho a criticar el teatro musical cobraron relevancia en el periodo entre 1780 y 1791 a causa de 
dos eventos que al parecer repercutieron en la opinión pública: el boom de la prensa periódica y la reapertura del teatro de los Caños del Peral. Estudiar las etapas iniciales de la opinión pública desde un ángulo particular -en este caso, los debates al torno al teatro musical- aportará ejemplos concretos sobre el caso español que evidencian los límites de la definición de esfera pública formulada por Jürgen Habermas ${ }^{1}$.

La presente investigación se centra en las reacciones de la prensa periódica frente al teatro musical, así como las reacciones de los compositores y cantantes de tonadillas frente a la prensa. Por tanto, se sitúa en el marco de los estudios de recepción, con énfasis en la naturaleza intermediática (prensa por un lado, teatro musical por otro) que caracterizó algunos de los primeros ejemplos de la opinión pública moderna. Como advierte el filólogo inglés Harold Love, es imposible concebir la esfera pública exclusivamente a partir de argumentos impresos, sino que debe considerarse la repercusión de tales impresos en las interacciones sociales en vivo ${ }^{2}$. Con el fin de explorar las intersecciones entre público literario y público teatral, este trabajo pone en diálogo artículos publicados en la prensa madrileña entre 1787 y 1789 con dos tonadillas de los compositores Blas de Laserna (El Diario, 1787) y Pablo Esteve (El teatro y los actores agraviados, 1787). La selección de artículos y obras musicales obedece a una continuidad temática, ya que todos ellos discuten los alcances y límites de la opinión en el medio concreto de la prensa periódica. El periodo a considerar abarca la década de 1780, debido al gran volumen de publicaciones periódicas que aparecieron durante esa década y hasta 1791, cuando quedaron prohibidas la mayoría de ellas, excepto las oficiales.

Las tonadillas de Laserna y Esteve se estudian desde una perspectiva tanto literaria como musical, considerando también aspectos puntuales del público que asistía a los teatros y un memorial del propio Laserna. En las anotaciones y correcciones, los mismos libretos y partituras ofrecen información respecto de las prácticas interpretativas, sin que por ello ni uno ni otro documento agoten las posibilidades de improvisación y variación del teatro musical. Además, las opiniones expresadas en la prensa presentan aspectos de la interpretación (performance) de la ópera y los bailes italianos de los Caños del Peral, tales como el timbre y emisión vocal. En el contexto de esta investigación, se consideran teatro musical los géneros breves como sainetes y tonadillas, la ópera italiana y los numerosos géneros mixtos que durante esta etapa incorporaron elementos hablados y cantados.

${ }^{1}$ El presente análisis utiliza la nueva edición de Strukturwandel der Öffentlichkeit: Unterschungen zu einer Kategorie der bürgerlichen Gesellschaft, revisada por Habermas en 1990 y traducida al español por Antonio Doménech con el título Historia y crítica de la opinión pública. La transformación estructural de la vida pública, Barcelona, Gustavo Gil, 1994.

2 Harold Love: "How Music Created a Public", Criticism, 46, 2, 2004, p. 267. 
Un análisis de los debates en torno al teatro musical demuestra que a finales del siglo XVIII, palabras como "crítica" "criticar" u "opinión" tenían múltiples acepciones, y que las personas usaban estos términos para referirse a más de un concepto. Para los fines de este trabajo, el término crítica se usará principalmente en dos sentidos. El primero, el de crítica periodística, definida como "juicio expresado, generalmente de una manera pública, sobre un espectáculo, una obra artística, etc." según la definición actual ${ }^{3}$. El segundo, el de la acción de criticar en su acepción de "hablar mal de alguien o de algo, o señalar un defecto o tacha suyos", o dicho de otro modo, como "ataque verbal o comentario negativo" ${ }^{4}$. La decisión se debe a que los artículos y tonadillas estudiados usan "crítica" casi siempre en estos dos sentidos. La frase "crítica de costumbres" se reserva para referirse a la connotación más profunda del término "crítica" como un análisis pormenorizado de los fenómenos culturales a partir de un aparato filosófico. Los artículos de opinión y crítica en la prensa se denominan "reseñas" u "opinión impresa" para enfatizar que se trata del género periodístico, y no del filosófico-moral, si bien existen intersecciones entre ambos.

La primera sección del artículo ofrece un panorama de la prensa periódica e investiga una serie de seis cartas publicadas en el Diario de Madrid en 1789. En esta serie de cartas se debate el valor de los cantantes y bailarines italianos frente a los españoles, así como el derecho de la crítica periodística a opinar sobre teatro musical. Las cartas muestran dudas sobre los beneficios que la opinión impresa puede traer a la sociedad, así como desconfianza ante el lenguaje usado por la crítica periodística. La segunda sección explora las reacciones de los compositores y actores teatrales frente al incremento en el volumen de la opinión impresa a través de dos tonadillas escénicas de Blas de Laserna y Pablo Esteve, ambas de 1787. Estas reacciones por parte de las tonadillas ilustran la resistencia al cambio de una concepción premoderna de opinión a otra que puede considerarse opinión pública en el sentido moderno. Finalmente, se ofrecen algunas conclusiones sobre las dos secciones a la luz de la teoría de Habermas sobre la esfera pública.

\section{El boom de la prensa y las opiniones impresas sobre el teatro musical}

Durante la década de 1780 la prensa floreció en España y, de manera especial, en Madrid. En parte, esto se debió a que hacia 1781 la producción de publicaciones periódicas comenzó a financiarse por medio de suscripciones, en lugar de depender de patrocinios del Estado, la Iglesia o individuos

\footnotetext{
3 Diccionario de la lengua Española, Edición del Tricentenario. 23. a ed., s.v. "Crítico, ca"/9, http://dle.rae.es/?id=BKJHGzW.

${ }^{4}$ Ibid., s.v. "Criticar"/2, y "Crítica"/13, http://dle.rae.es/?id=BKFoPJO.
} 
particulares. El sistema de suscripciones, si bien se había iniciado ya con Francisco Mariano Nipho en 1761, se hizo viable en 1781 gracias a una reducción de las tarifas postales y a un interés creciente en la prensa periódica que generó un número suficiente de suscriptores ${ }^{5}$. Ese mismo año salió a la luz El Censor (editado por Luis García Cañuelo), que quizá sea el periódico más original y autónomo del XVIII tardío. La década de 1780 fue también privilegiada porque la prensa gozó de relativo respeto por parte de las autoridades centrales españolas, encabezadas por el conde de Floridablanca como Secretario del Despacho de Estado. Inicialmente, las autoridades consideraron que la prensa podría funcionar como un instrumento para implementar las reformas que el gobierno de Carlos III y sus ministros venían promoviendo desde hacía más de una década a fin de modernizar a España económicamente para poder competir con otras naciones europeas $^{6}$. Poco después, como reacción a la Revolución francesa, y estando Carlos IV en el trono, Floridablanca mismo cambió su postura y en 1791 prohibió toda publicación periódica, dando fin con ello al apoyo estatal de la prensa, al menos temporalmente ${ }^{7}$.

En décadas previas, publicaciones como El Pensador de José Clavijo y Fajardo y Cajón de sastre de Nipho habían sido pioneras en la crítica de costumbres (Clavijo y Fajardo) y en las reseñas teatrales (Nipho), pero se trataba de casos más o menos aislados ${ }^{8}$. En cambio, en 1787 existía ya en Madrid suficiente volumen de periódicos como para generar un incipiente público lector y, con ello, una conversación sobre música y teatro. Dicha conversación tenía lugar de manera oral en las tertulias, en las calles y en el mismo teatro, pero ahora comenzaba también a ponerse por escrito ${ }^{9}$. Durante la década de 1780 continuaron publicándose la Gaceta de Madrid y el Mercurio histórico y político, que en 1784 cambió su título por el de Mercurio de España. Además de El Censor, aparecieron (entre otros) en 1781 el Correo literario de la Europa y en 1784 el Memorial literario, instructivo y curioso de la corte de Madrid, El correo de los ciegos, el Diario curioso, erudito, económico y

\footnotetext{
${ }^{5}$ Elisabel Larriba: Le Public de la presse en Espagne à la fin du XVIII siècle (1781-1808), París, Honoré Champion, 1998, p. 13.

6 Gabriel Torres Puga: Opinión pública y censura en Nueva España. Indicios de un silencio imposible 1767-1794, México, El Colegio de México, 2010, p. 195.

${ }^{7}$ Real Orden de 24 de febrero de 1791. Novísima recopilación de las leyes de España tomo IV, libro VIII, título XVII, ley V, p. 152. Fueron exceptuados el Diario de Madrid, el Mercurio de España y la Gazeta Literaria. No obstante, se prohibió al Diario publicar "versos, ni otras especies políticas". El Conde de Aranda revocó la prohibición en 1792, pero muchos de los periódicos iniciados en la década de 1780 cesaron de publicarse a raíz de la real orden de 1791.

${ }^{8}$ El Pensador se publicó en 1762-1763 y 1767 en la imprenta de Joaquín Ibarra. Cajón de sastre, o montón de muchas cosas se publicó entre 1760 y 1761 en la imprenta de Gabriel Ramírez, con periodicidad semanal. Otras publicaciones periódicas de la misma década incluyen El Belianis Literario, editado por Juan López Sedano en 1765, y el Semanario Económico iniciado por Pedro Araus en 1765.

9 Para la interdependencia entre prensa y conversación, ver Love: "How Music", p. 267.
} 
comercial (continuación de aquel iniciado por Nipho en 1758, y precursor del Diario de Madrid), El Apologista Universal y El Corresponsal del Censor vieron la luz en 1786, seguidos por el Espíritu de los mejores diarios, y el Semanario Erudito en 1787, año en el que El Censor dejó de publicarse ${ }^{10}$. A estos periódicos deben añadirse numerosos panfletos y libelos sobre temas particulares, frecuentemente en respuesta a artículos publicados en diarios y revistas. Una creciente clase media en las urbes españolas (médicos, abogados, militares, comerciantes, profesores, servidores públicos, arquitectos e ingenieros) permitió la consolidación del público lector, ya que dicha clase formó parte importante de las suscripciones periódicas, junto con la nobleza y el clero.

A la proliferación de publicaciones periódicas durante la década de 1780 se añade que en 1787 el Teatro de los Caños del Peral reabrió sus puertas con el fin específico de programar ópera italiana, evento que estimuló las opiniones impresas sobre el teatro musica ${ }^{11}$. La reinauguración de los Caños del Peral provocó comparaciones entre el teatro musical italiano y el español, las cuales se volvieron tema candente tanto en las tertulias como en la prensa durante algunos años. Estas comparaciones discutían desde la calidad de cantantes, actores y bailarines, hasta el comportamiento del público. Así, por ejemplo, el 21 de abril de 1787 el Correo de los Ciegos publicó una carta relatando una conversación imaginaria presenciada por un caballero con relación a la anual configuración de las compañías de cómicos de Madrid. Dicha conversación imaginaria compara los hábitos del teatro musical español con los de "otras cortes" europeas que el interlocutor ha visitado. La carta publicada en el Correo de los Ciegos pide que se corrijan una serie

${ }^{10}$ El Mercurio Histórico y Político fue fundado en 1738 por Salvador José Mañer, pasando en 1756 al cargo de la Secretaría de Estado hasta 1799. El Correo Literario de la Europa fue editado (probablemente) por Francisco Antonio Escartín y Carrera y publicado semanalmente en la oficina de Hilario Santos Alonso entre 1781 y 1787. El Memorial Literario, Instructivo y Curioso de la Corte de Madrid fue fundado por Joaquín Ezquerra y Pedro Pablo Trullenc, de publicación mensual entre 1784 y 1787, y quincenal entre 1787 y 1790, publicado en la Imprenta Real. El Correo de los Ciegos de Madrid fue editado por Antonio de Manegat, de publicación bisemanal entre 1786 y 1790, y semanal desde 1790 y hasta febrero de 1791. El Diario Curioso, Erudito, Económico y Comercial, fue editado por Jacques Thevin (Santiago Thewin) y publicado diariamente entre 1786 y 1787 en la imprenta de Manuel González; cambió su título por el de Diario de Madrid a partir de 1788. El Apologista Universal editado por Pedro Centeno y Joaquín Ezquerra publicó solo dieciséis números en 1786 en la Imprenta Real. Le respondió un único número de El Corresponsal del Apologista ese mismo año. El Corresponsal del Censor fue editado por Manuel Rubín de Celis y Noriega y publicado entre 1786 y 1788. El Espíritu de los Mejores Diarios Literarios que se publican en Europa fue editado por Cristóbal Cladera y publicado en un inicio tres veces por semana, después semanalmente entre 1787 y 1791 en la imprenta de José Herrera. El Semanario Erudito fue editado por Antonio Valladares de Sotomayor entre 1787 y 1791 y publicado semanalmente en la imprenta de Blas Román.

11 Sobre la reapertura del Teatro de los Caños del Peral, ver José Máximo Leza y Miguel Ángel Marín: "Ecos hispanos del clasicismo", La música en el siglo XVIII, Historia de la música en España e Hispanoamérica, vol. 4. 
de defectos en los teatros españoles para asemejarlos más a los teatros de ópera europeos: que los carteles anunciando las funciones sean impresos en vez de manuscritos, que se vendan billetes de antemano para evitar aglomeraciones, que no se venda agua dentro del teatro, que se construyan retretes inodoros y, finalmente, que se haga más estricta la censura de sainetes y tonadillas para desterrar "impropiedades" 12 . En general, para las clases medias y altas de Madrid, el Teatro de los Caños del Peral representaba una forma de entretenimiento "civilizada" en todos sus aspectos ${ }^{13}$.

El boom de la prensa introdujo una nueva forma de comunicación social que despertó interés e interrogantes entre los madrileños. Así pues, los debates sobre el teatro musical no solo abordaron el espectáculo dramático, sino también los términos en que había de desenvolverse la discusión acerca del mismo. Al igual que se criticó el desaliño de los coliseos locales y a las actrices españolas por sus limitaciones técnicas, también se censuró la calidad del discurso y de las opiniones. Por ejemplo, en la misma carta al Correo de los Ciegos del 21 de abril, el corresponsal reprueba la conversación caótica de los "apasionados" o hinchas de los coliseos de El Príncipe y La Cruz, mientras que alaba otras conversaciones más racionales. El autor concluye en estos términos: "He aquí en poco tiempo he oído disparates garrafales; despropósitos de marca; al fin como de apasionados; pero también he oído discursos bien formados, pensamientos útiles sostenidos de razones convincentes $[\ldots]^{14}$.

Las opiniones en torno a la reapertura de los Caños del Peral revelan dos posturas distintas con respecto a la posición que España debía tomar frente a Europa. Por una parte se encontraba un grupo de nobles, funcionarios, comerciantes y otros miembros de las clases altas que apoyaron el proyecto de los Caños con el fin de dotar a la capital española con un teatro que ofreciera un espectáculo internacional, como las casas de ópera en París y en otras ciudades europeas. Entre ellos se encontraban Juan Bautista Montaldi, banquero genovés residente en Madrid que fue por breve tiempo el primer arrendatario de los Caños del Peral, así como el Duque de Hijar, hermano mayor de la Junta de Hospitales, y más tarde el Marqués de Astorga, hermano mayor de la Asociación para la Representación de Óperas Italianas ${ }^{15}$. Este grupo tomaba como referencia las prácticas artísticas

\footnotetext{
${ }_{12}$ Correo de los Ciegos, 52, 21-4-1787, pp. 214-215.

13 Sobre el significado de "civilizar" ver José Antonio Maravall: "La palabra 'civilización' y su sentido en el siglo XVIII", Actas del Quinto Congreso Internacional de Hispanistas, vol. 1, Bordeaux, Université de Bordeaux, 1977, pp. 79-104. También José Escobar: "Más sobre los orígenes de civilizar y civilización en la España del siglo XVIII", Nueva Revista de Filología Hispánica, vol. 33, 1, enero 1984 , pp. 88-114.

${ }^{14}$ Correo de los Ciegos, n. ${ }^{\circ}$ 52, 21-4-1787, p. 215.

${ }_{15}$ Ver el capítulo X de Emilio Cotarelo y Mori: Orígenes y establecimiento de le ópera en España hasta 1800, Madrid, Tipografía de la Revista de Archivos, Bibliotecas y Museos, 1917, pp. 291-330.
} 
de las capitales europeas y se mostraba interesado por un teatro musical cosmopolita. Frente a ellos se situarían los asistentes asiduos a los coliseos de la ciudad, familiarizados tanto con los diversos géneros que se programaban en ese momento (comedias de magia, comedias heroicas y sentimentales, comedias del siglo de oro, sainetes, tonadillas, loas, fines de fiesta, y comedias con música en mayor o menor grado), como con los actores y actrices que las representaban ${ }^{16}$. Esta base popular del público, unida a grupos e individuos de tendencia conservadora pertenecientes a las clases medias y altas, opuso resistencia a las formas artísticas extranjeras, que eran percibidas como una amenaza a la cultura nacional.

\section{Seis cartas en el Diario de Madrid en 1789 sobre interpretación de ópera italiana}

Las comparaciones entre la ópera y el teatro musical español ocuparon a la prensa madrileña por espacio de algunos años, desde 1787 hasta 1791-1792. Entre julio y noviembre de 1789 se publicó en el Diario de Madrid una serie de seis cartas acerca de la calidad interpretativa de los artistas de la ópera italiana en los Caños del Peral ${ }^{17}$. Muy pronto, la discusión viró hacia el derecho a opinar y el tenor de las críticas mismas.

La serie de cartas inició el 26 de julio con un "Elogio a los autores, actrices, bailarines, ornato y orquesta de la ópera italiana" escrito por el compositor Antonio Rosales. Se advierten en la carta de Rosales las tendencias cosmopolitas que auspiciaron la reapertura de los Caños del Peral, pues comienza exhortando a los españoles a acoger a los cantantes de la ópera ya que "en todo país culto tienen los extranjeros un derecho absoluto de hospitalidad" 18 . Esta intervención en pro de los intérpretes extranjeros resultaba en sí controversial, dado que su presencia en Madrid había reavivado la llama de la defensa del teatro nacional ${ }^{19}$. Rosales cuida de expresar sus

\footnotetext{
16 Para la frecuencia con que cada género teatral específico se producía en Madrid en el siglo XVIII, ver Réné Andioc: Teatro y sociedad en el Madrid del siglo XVIII, Madrid, Fundación Juan March, 1976.

17 (1) 26-7-1789, n. ${ }^{\circ} 207$, pp. 825-826, por Antonio Rosales; (2) 21-8-1789, n. ${ }^{\circ} 233$, p. 229, respuesta de Marcelino Torrones; (3) 27-8-1789, n. ${ }^{\circ}$ 239, pp. 953-954, respuesta a Torrones por Juan Chamorro; (4) 10-9-1789, n. ${ }^{\circ}$ 253, pp. 1009-1010, respuesta de Gonzalo Bazo; (5) 13-10-1789, n. ${ }^{\circ}$ 286, pp. 1141-1142, respuesta de P.D.C.; (6) 28-29-11-1789, n. ${ }^{\circ} 332$, pp. 1325-1326 y n. ${ }^{\circ} 333$, pp. 1329-1330, Respuesta a P.D. Y C. por Joseph Teran. Las cartas de los nos 207, 233, 253 y 278 se encuentran transcritas en Yolanda F. Acker: Música y danza en el "Diario de Madrid" (1758-1808): noticias, avisos y artículos, Madrid, Instituto Nacional de las Artes Escénicas y de la Música, Centro de Documentación de Música y Danza, 2007, pp. 93-96.

${ }^{18}$ Antonio Rosales: "Elogio a los Autores, Actrices, Bailarines, ornato y orquesta de la Ópera Italiana", Diario de Madrid, n. ${ }^{\circ}$ 207, 26-7-1789, p. 825.

19 "La reivindicación de un teatro nacional estaba muy presente y Rosales, buen conocedor de ello, no duda sin embargo en manifestar su apoyo a los cantantes y artistas italianos...". Begoña Lolo y
} 
críticas en términos de elogios y alabanzas, evitando señalar los defectos de los cantantes y bailarines aun cuando los encontrara cortos de talento. En su opinión, los patrocinadores del proyecto de la ópera italiana "sirven al público" y se esfuerzan por complacerle con una diversión "grata y honesta". Rosales se refiere tanto al público teatral como a la esfera pública, pues señala que los ministros del rey "procuran decorarle [al Pueblo de Madrid], y mantener en él la más fina y exacta policía" 20 . Con estas palabras, esta primera carta presenta a la ciudad y al nuevo teatro de la ópera como espacios ordenados y civilizados que permiten el intercambio de opiniones.

Un mes más tarde, un corresponsal de nombre Marcelino Torrones respondió a Rosales diciendo que el público no está obligado a aceptar las manifestaciones culturales extranjeras indiscriminadamente. "En todo país culto, se distingue lo bueno de lo malo," apunta Torrones. Este autor caracteriza al "Pueblo de Madrid" como sujeto colectivo de opinión que "ve, oye, y conoce, para discernir las expresadas circunstancias" y "hacer justicia al mérito" 21 . Al contrario de Rosales, Torrones no duda en señalar las limitaciones de los intérpretes de la ópera y llega incluso a enjuiciar el aspecto físico de las cantantes y bailarinas ${ }^{22}$. Así, señala que la Sra. Benini "es limitada, le falta pecho, teatro, y su vestir no causa la mayor atención", y que "las demás partes cumplen, y trabajan sin particularidad en su obra, sin aquel fuego y actividad, que debe encarecer su mayor lucimiento"23. Torrones desaprueba que se escriban únicamente elogios sobre la ópera en los Caños del Peral, pues esto da a entender que el público madrileño no es capaz de distinguir lo bueno de lo malo. A su juicio, "un concurso tan ilustrado como el de la Corte de Madrid, están hechos a ver y oír los mayores primores, y que les es debido en toda justicia, la mayor decencia, gusto y armonía en todos los casos de unión publica, y particular, y de lo contrario sería conceptuar a la nación española de ridícula y brutal en la opinión de las demás naciones" ${ }^{24}$. La frase "unión pública" en esta carta parece de hecho referirse a la opinión pública. Las críticas de Torrones sobre los cantantes y bailarines causaron controversia, propiciando las respuestas de Juan Chamorro y Gonzalo Bazo, autores de la tercera y cuarta cartas respectivamente.

La tercera carta recurre a dos argumentos frecuentemente esgrimidos contra la opinión impresa: cuestionar la autoridad de los corresponsales de la

Germán Labrador López de Azcona: Antonio Rosales y la tonadilla escénica. La música en los teatros de Madrid I, Madrid, Comunidad de Madrid, 2005, p. 28.

20 A. Rosales: "Elogio", p. 826.

${ }^{21}$ Marcelino Torrones: "Carta en respuesta a la del Sr. Rosales de 26 de julio, sobre el mérito de los operistas, bailarines, etc.”, Diario de Madrid, n. ${ }^{\circ} 233,21-8-1789$, p. 229 (las cursivas son mías).

22 Escribe, por ejemplo, que la bailarina Rosa Pelosini desagrada a la vista por su obesidad.

23 Se refiere a la soprano Anna Benini Mengozzi, quien se estrenó como primera dama de la compañía de Los Caños del Peral en 1789. Cotarelo y Mori: Orígenes y establecimiento..., p. 312.

${ }^{24}$ Marcelino Torrones: "Carta en respuesta...", p. 229 (el subrayado es mío). 
prensa para hablar en nombre del público y renegar del vocabulario de la crítica periodística como una jerga sin sentido. La idea de que un individuo perteneciente a la clase media o alta (ya que no puede afirmarse que todos los estratos sociales tuvieran acceso a la prensa ${ }^{25}$ ) contrarrestara públicamente la opinión de otro resultaba ajena a muchos españoles, e incluso se consideraba arrogante. En otras palabras, ser miembro del público no confería autoridad para opinar, ni permitía hablar (o escribir) en representación de otros miembros del público. Por tanto, una reacción constante ante las opiniones y críticas, musicales o de otro tipo, era preguntar quién le otorgó al individuo la autoridad para opinar. El firmante de la tercera carta, "Juan Chamorro" 26 , reprime a Torrones por "creerse defensor del público sin licencia de Rey ni Roque" y por "meterse a censurar lo que no entiende". Además, una y otra vez se culpó a la prensa de usar palabras incomprensibles o inventadas ${ }^{27}$. Más adelante en la misma carta, Juan Chamorro acusa a Torrones de inventar una "jerga de nuevo cuño" cuando escribe que a la voz de la soprano Teresa Oltrabelli "le falta pecho y teatro", y que "anima su canto a los más elevados golpes" 28 . Como se verá más adelante, la tonadilla El Diario, de Laserna, alude también al lenguaje críptico de la prensa, accesible solo para unos cuantos y, según el autor, abierto a interpretaciones ambiguas.

La siguiente (cuarta) carta de la serie reaccionó también contra Torrones por atreverse a formular críticas negativas acerca de los cantantes y

\footnotetext{
${ }^{25}$ Para ver con detalle la composición social de los suscriptores a la prensa a finales del XVIII, se puede consultar el libro de Elisabel Larriba: Le public de la presse, Paris, Honoré Champion, 1998. De acuerdo con esta autora, $75 \%$ de los españoles eran analfabetos hacia 1780, por lo cual el simple hecho de suscribirse a un periódico era símbolo de estatus (Larriba, 32). La gran mayoría de los suscriptores a la prensa eran hombres (más del 97 \%), ya que mientras alrededor de un 43 \% de hombres sabían leer, sólo un $13 \%$ de mujeres estaban alfabetizadas (Larriba, 149). Las cifras que proporciona Larriba excluyen a los lectores que compraban números sueltos o leían ejemplares pertenecientes a otro suscriptor.

${ }^{26}$ Es probable que se trate de un pseudónimo. Se utilizaba también este nombre como un genérico para referirse a un hombre cualquiera. Juan Chamorro es también el nombre del sacristán en Fuenteovejuna.

27 Una carta publicada el 27 de octubre de 1787 en el Diario curioso, erudito, económico y comercial (que a partir de 1788 se llamaría Diario de Madrid) ofrece un ejemplo más del argumento de la "jerga" de la crítica periodística. Esta carta ataca a un corresponsal previo que elogiara a autores como Batteux y Voltaire, arguyendo que su admiración por los pensadores franceses le llevaba a no usar correctamente la gramática española, a ser "un español sin lenguaje." Continúa la carta descartando el elogio de los autores franceses como mera palabrería: "Vmd. habla mucho, y por eso yerra tanto. Vmd. quiere reflexionar demasiado, y como no es lo mismo proponer que probar, le falta lógica, crítica, y dialéctica, y lo que es mas, inteligencia, al paso que le sobran dicterios y arrogancia". Mariano de Mina: Diario Curioso, Erudito, Económico y Comercial, n. ${ }^{\circ} 484,27-10-1787$, p. 479.

${ }_{28}$ Juan Chamorro: "Carta de Juan Chamorro al Sr. Marcelino Torrones", Diario de Madrid, n. ${ }^{\circ} 239$, 27-8-1789, pp. 953-954. La cantante italiana Teresa Oltrabelli estuvo en Madrid como primera bufa de la compañía italiana de los Caños del Peral en los años 1787-1788. De acuerdo con Cotarelo y Mori, cuando Oltrabelli llegó a Madrid "ya no estaba en la juventud ni tenía mucha voz, aunque sí gran dominio de la escena y costumbre de representar". Cotarelo y Mori: Origen y establecimiento..., p. 298. Oltrabelli también se encuentra listada en Luis Carmena y Millán: Crónica de la ópera italiana en Madrid desde el año 1738 hasta nuestros días, Madrid, Imprenta de Manuel Minuesa de los Ríos, 1878, p. 422.
} 
bailarines, confirmando que la opinión impresa se leía muchas veces como un ataque personal, potencialmente destructivo, y no como expresión de un punto de vista. Esto se debe a que la opinión pública no ocupaba una categoría epistemológica en la Weltanschauung (cosmovisión) española del XVIII tardío, sino que el término "opinión" se entendía en función de la reputación o "fama" maquiavélica: como una corte implícita en la cual un grupo de gente juzgaba las acciones públicas y privadas de un individuo ${ }^{29}$. En este contexto, las opiniones expresadas en las reseñas de teatro musical parecían sentenciar a las actrices/actores, amenazando con destruir su reputación ${ }^{30}$. Entendiendo la opinión como juicio determinante del valor de una persona, Gonzalo Bazo (autor de la cuarta carta en el Diario de Madrid) se muestra confuso porque Torrones mezcle en su escrito comentarios positivos y negativos. No le queda claro a Bazo cuál es el veredicto de Torrones, y concluye que su carta "es tan oscura, que no puede saberse si destruye, o apoya, si es crítica, o apologética, ni si es menestra o pepitoria" ${ }^{31}$. Las palabras de Bazo muestran asimismo su confusión sobre el género periodístico, el cual asocia con la crítica, pero también con la apologética que en la década de 1780 había cobrado ímpetu, especialmente a raíz de la obra de Juan Pablo Forner $^{32}$. Bazo recurre al cliché del lenguaje oscuro de la prensa, quejándose hacia el final de la carta de que Torrones "habla unas veces en vascuence, otras en castellano, y ninguna con orden ni método".

El autor de la quinta y penúltima carta de la serie comienza aplaudiendo a los editores del Diario por publicar todo tipo de críticas mientras estas no se excedan, dado que así el propio público lector discernirá las opiniones inteligentes de las que no lo son. La carta parece concebir la opinión pública como una votación y el periódico como una urna donde se depositan los votos, unos a favor de la ópera de los Caños del Peral, otros en contra. Así, compara las cartas del Diario con "papelillos" que se echan en una cajita. Esta concepción no aspira a democratizar el acceso a la opinión, sino a hacer de

\footnotetext{
29 Gonzalo Capellán de Miguel: "Introducción. Los 'momentos' de la opinión pública", Opinión pública, historia y presente, Madrid, Editorial Trotta, 2008, pp. 11-12. Ver también Jeffrey A. Bowman: "Infamy and Proof in Medieval Spain", Fama: The Politics of Talk \& Reputation in Medieval Europe, Thelma Fenster y Daniel Lord Small (eds.), Ithaca, Cornell University Press, 2003, pp. 95-117.

30 Si bien no existía el concepto de opinión pública como herramienta política, sí existía aquel de opinión como un juicio no absoluto, que coexistía con otros opuestos. En el Diccionario de autoridades se encuentran la siguientes definiciones de "opinión": (1) "Dictamen, sentir, o juicio que se forma de alguna cosa, habiendo razón para lo contrario"; (2) "Significa también fama, o concepto que se forma de alguno". Diccionario de la lengua castellana compuesto por la Real Academia Española, 2a . ed., Madrid, Joaquín Ibarra, 1783, s.v. "opinión”.

31 Gonzalo Bazo: "Carta contra la del viernes 21 de agosto, sobre el mérito de las actrices, bailarines, grotesco y orquesta de la ópera", Diario de Madrid, n. ${ }^{\circ} 253,10-9-1789$, p. 1010.

32 Juan Pablo Forner: Oración apologética por la España y su mérito literario para que sirva de exornación al discurso leído por el Abate Denina en la Academia de Ciencias de Berlín, respondiendo a la cuestión Qué se debe a la España, Madrid, Imprenta Real, 1786.
} 
Madrid, con su teatro musical y sus periódicos, una ciudad europea cosmopolita e ilustrada ${ }^{33}$. Para este autor, los corresponsales anteriores (excepto Torrones) no conocen más que la realidad local, de manera que forman sus juicios a partir de lo que oyen en "el cafe, Prado, y tertulias de puerta de calle, no tratando en estos sitios sino con otros tales como ellos, por lo que nunca salen de su ignorancia". En consecuencia, carecen de inteligencia para "dar voto" sobre un género internacional como la ópera:"Otro día se les dirá más, hasta que se logre establecer entre ellos la máxima de que no hay cosa más risible en el mundo, que el oír dar a uno su voto sobre una materia que es público no entiende" ${ }^{34}$. El argumento de esta carta separa el sector popular del público ("de tertulias de puerta de calle") del ilustrado.

Llegado este punto, la discusión se vuelve hacia la naturaleza de la crítica y de la opinión impresa, mostrando la ambivalencia con que estas prácticas eran recibidas en la época. Dado que la crítica periodística como género apenas estaba consolidándose en Europa durante el siglo XVIII, los lectores de la prensa española se preguntaron si, y en qué condiciones podía hacerlo, la reseña musical y teatral traía algún beneficio a la sociedad. La sexta y última carta de la serie, por ejemplo, sugiere que la crítica periodística puede "resultar en beneficio de los mismos actores, pues unos con el estímulo de los elogios de aquellas [apologías y críticas] procurarán su adelantamiento, y otros por el temor de esta lo harán con mayor esmero" 35 . En última instancia, se cuestionó si la opinión impresa llevaría a la utilidad y deleite al público, que debía ser el fin de todo arte y de toda publicación de acuerdo con el ideario ilustrado, y también con la preceptiva neoclásica $^{36}$. Siguiendo el principio de utilidad pública, los periódicos consideraron suya la responsabilidad de orientar a los lectores en las secciones dedicadas a la música y el teatro ${ }^{37}$. Incluso hubo quien vio en la reseña periodística la oportunidad para crear un discurso sobre las artes que, por ser

33 "Es innegable que su periódico de Vmds. va siendo cada día más apreciable, y que una de las cosas que más sientan su mérito, es la imparcialidad con que incluyen en él las ideas que cada uno les propone, buenas, o malas, dejando el campo abierto para las críticas, que sin pasar de los términos regulares, tienen que sufrir los que aspiran a ver sus miserables producciones en letra de molde. Qué excelente idea esta, para contener a tales pedantes, y animar a las gentes de talento a que publiquen en beneficio del común sus concepciones, y poder hacer así un fundado discernimiento de lo útil e inútil". P.D.C.: "Carta contra los que han escrito en pro y en contra de la ópera, los operistas, bailarines, etc.", Diario de Madrid, n. ${ }^{\circ}$ 286, 13-10-1789, p. 1141.

${ }^{34}$ Ibid., 1142.

35 José Terán: "Carta de Don José Terán, contra la del Sr. D.P.D. y C. publicada en el Diario del día 13 del próximo mes pasado", Diario de Madrid, n. ${ }^{\circ} 333,29-11-1789$, p. 1329.

${ }^{36}$ La poética de Ignacio de Luzán establece el doble fin de deleitar y ser útil en el capítulo XI, "Del fin de la poesía". La Poética, o reglas de la poesía en general y de sus principales especies, Zaragoza, Francisco Revilla, 1737, pp. 56-59.

${ }^{37}$ Como una muestra, el prospecto del Memorial Literario, Instructivo y Curioso tiene como intención ofrecer no solo reseñas del argumento de las obras teatrales, sino también "un juicio que hicieren los inteligentes sobre su perfección y defectos". Memorial Literario, enero 1785, p. 7. 
conciso y de fácil acceso, cumpliría mejor con el ideal neoclásico de instruir y enseñar." 38 No obstante, buena parte de la población madrileña siguió sospechando de la opinión impresa.

\section{Tonadillas, periódicos y censura: El diario (Blas de Laserna, 1787)}

Además del derecho de los ciudadanos comunes a intervenir en la opinión pública y de la utilidad de la crítica periodística, se cuestionó la validez de la prensa como instrumento del conocimiento y de la comunicación social. En cuanto a la posibilidad de generar conocimiento, el formato corto y misceláneo de los periódicos supuso una novedad y causó sorpresa. Muchos madrileños no entendían cómo un impreso de pocas páginas, que mezclaba asuntos varios, podía aportar algún conocimiento valioso, sobre todo si se comparaba con otros impresos como las obras clásicas o las disertaciones espirituales ${ }^{39}$. La sospecha ante el formato periodístico y el conocimiento que producía, comparados con el formato y conocimiento de libros y tratados, se relaciona con dos formas diferentes de entender la crítica que se encuentran registradas en la primera edición del Diccionario de la lengua castellana (Diccionario de autoridades) ${ }^{40}$. Publicada en 1729, la entrada "Criticar" ofrece dos acepciones. La primera es "examinar y hacer juicio de alguna obra, libro o escrito, para declarar o discernir lo cierto y verdadero de lo falso y dudoso". Este tipo de crítica suponía un conocimiento a fondo que permitía llegar a la verdad. La segunda acepción dice que criticar "vulgarmente se toma por censurar, formar sin conocimiento juicio de las obras y escritos, con cierta especie de murmuración y mofa" 41 . Este segundo significado del término se aproxima más al de "difamación",

\footnotetext{
${ }^{38}$ Esta postura queda evidente en una carta publicada en el Diario de Madrid el 19 de octubre de 1789, en medio del debate epistolar sobre los operistas y bailarines de los Caños del Peral, y firmada por Juan Antonio Godínez. Comienza así la carta: "Mis señores: ¿Debe ser un poeta filósofo? O lo que es lo mismo, ¿un orador, músico, arquitecto, pintor, todos aquellos que emplean sus años en obras de la imaginación deben discurrir? ¿Han de ser filósofos, o aniquilan filosofando el deleite que de otra suerte causarían sus obras en las gentes de buen gusto?" Godínez teme que discurrir por escrito sobre el teatro puede "resonar a jerga escolástica" si cae en una "tosca aridez que fastidie a los lectores, o [en] un inútil deleite...". Pone como modelo para el discurso sobre las obras creativas a Mengs y a Condillac. Juan Antonio Godínez: "Carta instando a que el buen poeta debe acompañar la poesía con la filosofía", Diario de Madrid, n. ${ }^{\circ} 292,19-10-1789$, pp. 1165-1166.

${ }^{39}$ Esta diferencia entre periódicos y libros según su extensión se encuentra recogida en una real orden de 1785, según la cual los papeles periódicos "cuando no pasen de cuatro o seis pliegos impresos" corre a cargo del juez de imprentas, mientras "los libros formales y obras de mayor extensión" deberán ser examinados por el Consejo (de Castilla). "El examen y las licencias...", Novísima recopilación tomo IV, libro VIII, título XVII, ley IV, p. 152.

${ }^{40}$ Publicado entre 1726 y 1739.

${ }^{41}$ Real Academia Española: Diccionario de la lengua castellana, en que se explica el verdadero sentido de las voces, su naturaleza y calidad... Tomo segundo, que contiene la letra C, Madrid, Imprenta de Francisco del Hierro, 1729, p. 661.
} 
que tiene sus raíces en el concepto medieval de "infamia"42. A pesar de que la prensa periódica se esforzó muchas veces por hacer justicia al primer significado de "crítica", repetidamente se le acusó caer en el segundo. Así, se tachó a los periódicos de superficiales y malintencionados, marabuntas de palabras y puntos de vista cuyo único objetivo era confundir al público.

Al desconcierto del público ante la función de la prensa y de la opinión se unía el recelo de las autoridades censoras, quienes tampoco habían definido su postura del todo - al menos durante la década de 1780-. Dado que toda publicación, incluidas las obras teatrales y las letras de las tonadillas, debía pasar por la censura, los autores tomaban medidas para evadir prohibiciones. El mismo Bazo confiesa al final de su carta que "si no temiera oponerme, o faltar en algo a las sabias providencias del Gobierno, que no permiten críticas importunas, ni que se ofenda el decoro del teatro, ni de los actores, haría más extensa mi contestación..." ${ }^{43}$. En general, las autoridades censoras permitían críticas auspiciadas por la cristiana intención de estimular al criticado a mejorar, es decir, críticas edificantes. La preceptiva neoclásica de Ignacio de Luzán indicó que solo es válida la sátira que critica los vicios generales de la población, y no los de un individuo ${ }^{44}$. Siguiendo esta línea, el imperativo legal para publicar críticas y sátiras consistía en "decir el pecado pero no el pecador", es decir, señalar los defectos sociales más que los personales, y abstenerse de nombrar individuos concretos ${ }^{45}$. Esta norma llevó a los autores a usar pseudónimos, alegorías, y toda clase de claves oscuras para dar a entender el objeto de sus críticas sin ser censurados.

De hecho, no solo los censores recelaban de posibles ataques impresos contra las autoridades o la sociedad en general, sino que los autores mismos temían ver su reputación dañada como consecuencia de publicar sus opiniones, como se vio en las cartas del Diario de Madrid de 1789. Es decir, si bien publicar una opinión ofrecía la oportunidad de participar de la república de las letras y del discurso social, también exponía al autor tanto a represalias y burlas como a sanciones oficiales por parte de la censura. Esta puede ser una de

\footnotetext{
42 Bowman: "Infamy and Proof in Medieval Spain", pp. 98-99. De acuerdo con Bowman, el concepto de infamia se puede encontrar ya en documentos visigóticos del siglo VII, y más tarde en las Siete Partidas de Alfonso X, del siglo XIII. La infamia de una persona se fundamentaba en testimonios orales, y tenía consecuencias legales de gran peso.

43 Gonzalo Bazo: Diario de Madrid, n. ${ }^{\circ} 253,10-9-1789$, p. 1010.

${ }^{44}$ Nigel Glendinning: "La sátira en el arte y la literatura en la época de Carlos IV", La época de Carlos IV, Elena de Lorenzo Álvarez (ed.), Oviedo, Instituto Feijóo de Estudios del Siglo XVIII, 2009, pp. 17-39.

45 "Así los censores como los autores y traductores cuidarán mucho, de que en sus papeles o escritos no se pongan expresiones torpes ni lúbricas, ni tampoco sátiras de ninguna especie, ni aun de materias políticas, ni cosas que desacrediten las personas, los teatros e instrucción nacional [...]". "Reglas que deben observarse en los papeles periódicos, y escritos cuya impresión corra bajo la inspección del juez de imprentas", Novísima recopilación, tomo IV, libro VIII, título XVII, ley III, p. 150. Glendinning observa que la censura contra sátiras públicas de personas específicas no se levantó sino hasta 1808. Glendinning: "La sátira", p. 18.
} 
las razones por las que los letristas de las tonadillas escénicas permanecían casi siempre en el anonimato, aunada al poco prestigio literario del género.

La tonadilla a solo El diario, escrita por Blas de Laserna en 1787, refleja algunas de las sospechas en contra de la prensa combinadas con la curiosidad que suscitaba su potencial para moldear la opinión del público. Aunque las tonadillas escénicas eran un medio predominantemente oral (las letras no solían imprimirse), compartían algunas características con los periódicos, tales como su formato breve compuesto por varias secciones contrastantes, y una vigencia temporal limitada, orientada a tratar asuntos de actualidad y entretener ${ }^{46}$. Este era sobre todo el caso de las tonadillas a solo, donde la actriz-cantante interpelaba al público como interlocutor, en segunda persona, comentando las modas y preocupaciones de cada momento ${ }^{47}$. Además, era frecuente que el público de ambos medios (prensa y tonadillas) fuera similar, ya que muchos de los suscriptores a los periódicos asistían también a los coliseos desde los palcos. Por ello, es posible identificar una intersección entre lectores de prensa periódica y audiencias teatrales. A los suscriptores de los periódicos deben añadirse aquellos que lograban hacerse de algún ejemplar de la prensa, y los que la oían leer en voz alta, lectores por extensión que también formaban parte del público teatral.

El diario de Laserna presenta la estructura estándar de las tonadillas a solo entre las décadas de 1770 y 1790 , al estar compuesta por una introducción, las coplas y las seguidillas finales, que en este caso son sustituidas por un "final". En la introducción, la tonadillera anuncia que presentará "un diario muy nuevo" con "mil cosas extrañas que algunos no comprenderán". Con ello Laserna y su letrista aluden al supuesto lenguaje críptico de la prensa, pero también a las críticas encubiertas para protegerse de represalias, puesto que en este diario ficticio "los defectos bien se entienden" aunque se utilicen metáforas. Laserna se resguarda de la censura aclarando que el diario "solo se dirige a enmendar el fiero horror", es decir, tiene una finalidad edificante, que es enmendar las malas intenciones. Si bien no queda claro cuál es el "fiero horror" (¿error?) que el diario debe enmendar,

\footnotetext{
${ }^{46}$ De acuerdo con Begoña Lolo, la tonadilla escénica "acabó convirtiéndose en un género en el que a través de la música se ilustraba a los concurrentes sobre la vida cotidiana, en un elemento de difusión de la actualidad más trepidante, en una especie de noticiero periodístico [...] con gran aceptación popular". "Itinerarios musicales en la tonadilla escénica", Paisajes sonoros en el Madrid del s. XVIII: la tonadilla escénica, Madrid, Museo de San Isidro, 2003, p. 16. En cuanto al carácter misceláneo de los periódicos, en su estudio sobre la prensa española en el siglo XVIII, Paul Guinard describe las publicaciones periódicas como un popurrí de comentarios breves, anécdotas, alegorías, cuentos, poemas, ensayos cortos, cartas y artículos más largos en emisiones sucesivas. La Presse espagnole de 1737 à 1791, formation et signification d'un genre, Thèses, mémoires et travaux, 22, París, Centre de Recherches Hispaniques, Institut d'Études Hispaniques, 1973, p. 233.

${ }_{47}$ Por el contrario, las tonadillas grupales (a dúo, a tres o más) normalmente tenían una trama ficticia, que si bien parodiaba situaciones reales, no las abordaba directamente. En las tonadillas a solo, las actricescantantes se representaban a sí mismas, mientras que en las grupales, representaban a otros personajes.
} 
el compositor lo enfatiza con un melisma que desciende una octava y media desde la tónica (Si bemol) hasta la dominante $(\mathrm{Fa})$ sobre un pedal en la subdominante en preparación para la cadencia de la introducción. Esta hipérbole musical en la palabra "horror" garantiza la ortodoxia del diario ficticio y, de paso, de la tonadilla ${ }^{48}$.

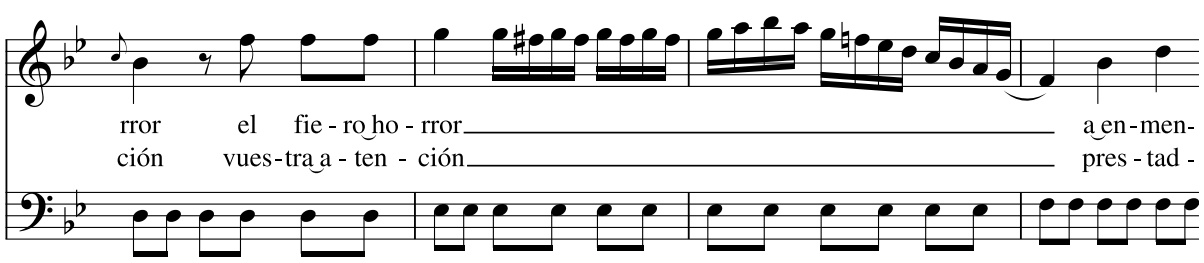

Ejemplo 1: "El fiero horror", fin de la introducción de la tonadilla a solo El diario de Blas de Laserna (1787) (Biblioteca Histórica Municipal de Madrid, Mus 87-5)

A continuación, Laserna y su letrista concibieron cada copla como una sección del diario, y el compositor anotó en la partitura que una voz debía gritar el título de la sección correspondiente a la copla. Por ejemplo, para la primera copla, la voz pregonaría “¡Literatura!”, y a continuación la tonadillera cantaría el contenido de la sección tal como si estuviera leyendo un periódico. Las secciones de $\mathrm{El}$ diario incluyen literatura, pérdidas, hallazgos, ventas, nodrizas y alquileres. Cada una satiriza un tema de moda: la prensa, los perritos falderos, los currutacos, el dinero nuevo de los indianos, los mayorazgos y el alto costo de los alquileres. De especial interés resulta la copla correspondiente a la sección "literatura", por hacer metarreferencia a la prensa de suscripción que se enviaba por correo:

Por un escritor de moda se imprime un librito nuevo que contiene doce ciencias y puede ir por el correo.

Los sabios modernos que acudan a suscribirse perderán tiempo y dinero.

Como ilustra esta copla de El diario, las tonadillas de las décadas de 1780 y 1790 sirvieron en Madrid para debatir sobre la necesidad de la opinión impresa en el proceso de modernización nacional, y aun sobre la misma necesidad de esta modernización. La copla subsume la prensa periódica

48 Todas las tonadillas a ser cantadas en los coliseos de Madrid debían pasar por los censores, encabezados en esta época por Santos Díez González. 
dentro del tópico de la moda, tan manido en la sátira del dieciocho tardío. Numerosas tonadillas y sainetes, así como artículos de prensa y panfletos, se valieron de la dicotomía antiguo/moderno para desacreditar las costumbres contemporáneas, creando su propia versión de la querella entre antiguos y modernos. La moda y lo moderno se referían a los hábitos sociales efectivamente asociados con la modernidad europea y con "lo ilustrado", tales como el esparcimiento social en espacios públicos que incluía la conversación, los bailes, las tertulias y la asistencia al teatro. Dentro de este tópico, tonadillas y sainetes desdeñaban lo moderno como falto de sustancia, como una imposición del extranjero ajena al carácter nacional. Tal como lo refleja esta copla sobre literatura en El diario, la prensa en un principio se consideró como un fenómeno que, si bien se había consolidado en otros países europeos, quizá fuera moda pasajera en España. Como se verá a continuación, esta postura no refleja necesariamente la de Laserna, pero sí una percepción difundida entre ciertos sectores madrileños.

Dado que las letras de las tonadillas no se imprimían, sino que solo se escribían en manuscrito para los censores y para los músicos y actores, las críticas en El diario llegan a ser un tanto arriesgadas. Por ejemplo, la sección "nodrizas" dice que una burra es la mejor ama de cría para un niño heredero de un mayorazgo ${ }^{49}$. Si tal burla se hubiera destinado a la imprenta en vez de ser transmitida oralmente, es posible que los censores se hubieran mostrado más estrictos, aunque no existen suficientes datos para probar esta hipótesis más allá de la sospecha general que reinaba en la época hacia la palabra escrita. Cabe recordar que así como las tonadillas tenían una existencia manuscrita (para los censores, músicos, y actores) y otra oral (para el escenario), la prensa también se leía en voz alta a familiares y amigos, práctica que ampliaba su radio de influencia en la opinión pública ${ }^{50}$. Con el tiempo, determinar la validez de las críticas según sus intenciones benévolas resultó difícil para las autoridades censoras, por lo que a partir de $1788^{51}$ la legislación de la prensa se tornó más estricta, culminando en la prohibición emitida por Floridablanca en 1791.

Aunque se desconoce al letrista de El diario, se sabe que Laserna estaba interesado personalmente en la prensa, interés que pudo llevarlo a elegir este

${ }^{49}$ Debe tenerse presente que el debate sobre el sistema de mayorazgo estaba muy presente en la España de finales del XVIII. Fue criticado, entre otros, por Jovellanos en su Informe en el Expediente de la Ley Agraria (1795), escrito a petición de la Sociedad Matritense de Amigos del País, que inspiraría la Desamortización de Godoy en 1798.

${ }^{50}$ Guinard estima que un solo ejemplar de una revista especializada alcanzaba hasta cinco lectores, ya fuera porque el ejemplar circulaba o porque se leía en voz alta. La prensa informativa y de crítica llegaba hasta a diez o quince lectores (u "oyentes") por ejemplar. Guinard: La Presse espagnole..., pp.70 y 233.

${ }^{51}$ Por real orden de 2 de octubre de 1788 se publicaron las "Reglas que deben observarse en los papeles periódicos, y escritos cuya impresión corra bajo la inspección del juez de imprentas". Novísima recopilación, tomo IV, libro VIII, título XVII, ley III, p. 150. 
tema para una tonadilla. De hecho, en 1795, junto con Fernando Romero y Pedro Rodríguez, solicitó permiso para iniciar un memorial (revista) dedicado al teatro con el título Espíritu del teatro. El permiso fue denegado. Según la petición, parte del objetivo de este memorial sería publicar las letras del teatro cantado con comentarios orientados a aclarar las intenciones del autor. Laserna y sus coeditores temían que, al no contar con transcripciones de los textos, el público no podría entender todas las palabras y malinterpretaría el significado de la pieza musical ${ }^{52}$. El debate sobre si imprimir o no las letras de las tonadillas había comenzado años antes, coincidiendo con el auge de la prensa en la década de 1780. De hecho, en 1787 los editores del Correo de los Ciegos (o Correo de Madrid) intentaron obtener autorización para imprimir las letras de las tonadillas en su periódico y, para ello, dirigieron la petición a Juan Laví y Zavala, administrador de los coliseos de La Cruz y El Príncipe. Sin embargo, los autores (administradores) de las compañías de teatro, por aquel entonces Manuel Martínez y Eusebio Rivera, protestaron enérgicamente en contra arguyendo que, al publicarse los textos de antemano, el público perdería el interés por asistir a la función. Asimismo temían que imprimir las letras diera pie a críticas más acendradas. Los asistentes, razonaban Martínez y Rivera en su queja, se presentarían al teatro con armas para atacar a los actores-cantantes; tal vez sea esta una de las primeras alertas contra los peligros de un público bien informado relacionada con la prensa en España ${ }^{53}$. La negativa de los administradores de los coliseos confirma asimismo sus esfuerzos por mantener la tonadilla en el ámbito de lo oral, quizá con la esperanza de esquivar la estricta reglamentación de la prensa.

\section{Tonadillas, "los críticos" y el público: El teatro y los actores agraviados (Pablo Esteve, 1787)}

Aunque hoy en día las críticas y reseñas periodísticas forman una parte esencial del mundo del espectáculo, en el siglo XVIII tomaron al teatro madrileño por sorpresa. Una vez que se empezaron a multiplicar las críticas teatrales, como las ya discutidas en torno a la ópera de los Caños del Peral, los actores-cantantes, compositores y escritores se sintieron blancos de ataque. En respuesta, escribieron cartas, artículos y también piezas teatrales y

\footnotetext{
52 "Cuando el drama fuere en música se anticipará la letra de aquellas arias, rondoes, etc. que contengan sentencia o particularidad digna de atención, y asimismo la de las tonadillas que las más veces no producen en el público la sensación que debieran a causa de robarles su inteligencia, burlando el esmero del compositor, la precisión de los tonos, o la oscura pronunciación de los actores". Extraído de la petición de Laserna en 1795, publicada por María José Rodríguez Sánchez de León: "Tres intentos fracasados de publicar una revista de teatros (1795, 1802 y 1804)", El siglo que llaman ilustrado: homenaje a Francisco Aguilar Piñal, Madrid, Consejo Superior de Investigaciones Científicas, 1996.

53 "Papeles referentes a los teatros de Madrid", compilados por Francisco A. Barbieri. Biblioteca Nacional de España, MSS/14016/3, 183
} 
musicales en su propia defensa. De hecho, en 1785 y por mandato de Carlos III, la ley reconoció el derecho a defenderse contra "cualquier obra impresa" y a demandar retractación pública, posiblemente porque los ataques y contraataques habían alcanzado un punto álgido ${ }^{54}$. En este contexto un tanto acalorado, la prensa y los escenarios sostuvieron debates acerca de quién tenía derecho a formular críticas sobre las producciones teatrales. Así se observa en la tonadilla a tres El teatro y los actores agraviados, de 1787, con música del compositor Pablo Esteve (ca.1730-1794).

En El teatro y los actores agraviados, Esteve y su letrista, en la voz del famoso cómico Miguel Garrido (1745-1807) y sus coetáneos Josefa Torres y Alfonso Navarro, protestan contra los "papelotes" (la prensa) que critican al teatro español. Esta tonadilla califica a "los críticos" de pedantes, es decir, aquellos que se precian de sabios sin serlo ${ }^{55}$. La materialidad de la opinión impresa se lleva a escena al indicarse que Garrido aparezca en la introducción "con diarios, censores y papeles en la mano". Se observa, pues, que el papel representaba por metonimia a la opinión impresa ${ }^{56}$.
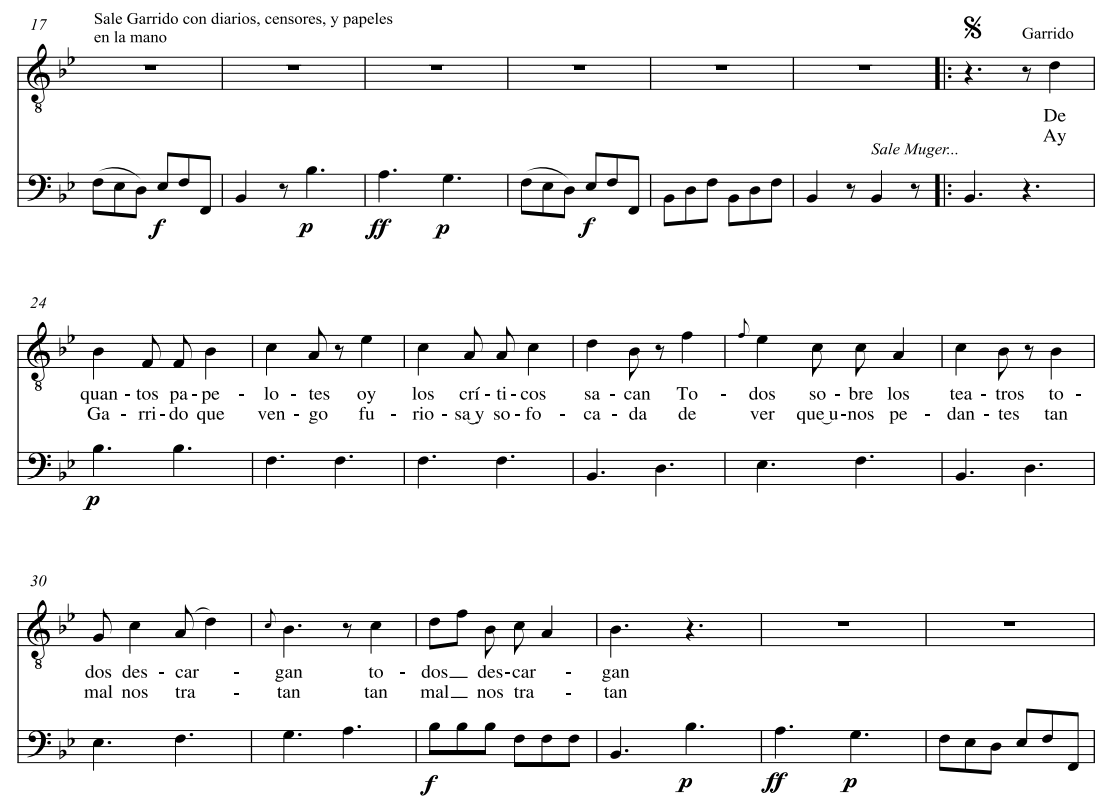

Ejemplo 2: Principio de la línea vocal de la introduccción en la tonadilla a tres El teatro y los actores agraviados de Pablo Esteve (1787). Lineas de voz y bajo (Biblioteca Histórica Municipal de Madrid, Mus 146-3)

54 [Carlos III], por real resolución de 19 de noviembre de 1785, comunicada al Consejo y Juez de Imprentas. "El Juez de Imprentas oiga y administre justicia al que se queje del autor de cualquier impreso", Novísima recopilación, tomo IV, libro VIII, título XVI, ley XXXIV, p. 142.

${ }^{55}$ La misma acusación de pedantería se lee en la quinta carta de la serie de 1789 en el Diario de Madrid.

${ }^{56}$ Asimismo, se denominaba "censores" a la prensa crítica, por El Censor, quizá la más sofisticada publicación en esta línea. 
Más adelante, en la segunda parte de la introducción a El teatro y los actores agraviados, se equipara "crítica" con "murmuración", refiriéndose a la crítica periodística como una conversación cuyo objeto era perjudicar la reputación del prójimo, es decir, dentro del marco de la "fama" medieval y renacentista:

Críticos satíricos que sin compasión

a todos ultraja su murmuración.

A la introducción sigue un allegretto al estilo de seguidillas, en el cual Garrido acusa a los críticos de escribir únicamente con fines de lucro "para sacar los cuartos a los lectores". Las coplas a su vez revelan que el agravio proviene más específicamente de las percepciones negativas que los autores neoclásicos tenían del teatro popular español. Los cantantes se quejan de que los críticos "se burlan de las comedias que al pueblo representamos [los actores]", y "critican que bailemos con los disfraces de diablo", en referencia al desdén ilustrado por las comedias de santos y de magia.

Al igual que las cartas del Diario de Madrid, la primera copla de El teatro $y$ los actores agraviados relaciona la crítica impresa con la capacidad que tiene el público de Madrid para opinar y formar juicios. Según esta tonadilla, aquellos que publican sus críticas se creen mejor calificados que el común del público:

Mas chito chitito, que pueden oír los sabios sujetos critica-defectos, que sus malos picos tratan de borricos a los de Madrid.

Así, la opinión impresa se considera no como opinión pública, sino como la actividad de un grupo privilegiado desconectado del pueblo en general, e inclusive en su contra. Los actores-cantantes se ponen del lado del público, mientras que pintan a "los críticos" como el antagonista común que los menosprecia. Con ello, la tonadilla refuerza la percepción de la opinión impresa y aun de la reseña periodística como una práctica ajena a lo nacional (o en este caso, a la comunidad local), una erudición intrusa que difama a los "poetas antiguos" 57 .

Además de intrusa, la crítica periodística aparece en esta tonadilla como una fuerza destructiva para el teatro nacional. Los cantantes así lo manifiestan en las seguidillas que preceden a las coplas. El tempo de allegretto y

\footnotetext{
${ }^{57}$ Cuarta copla: "Si los poetas antiguos se vieran tan difamados/ a sus críticas y a ellos [los críticos] los comieran a bocados".
} 
las rápidas ornamentaciones características del género expresan bien la agitación de los actores-cantantes ante la "turba de censores":

Tal turba de censores

se han levantado

que a sátiras destruyen

nuestros teatros.

El teatro se consideraba blanco vulnerable de la opinión impresa por estar ligado a la instrucción nacional. Es decir, criticar al teatro significaba cuestionar las instituciones destinadas a educar al público.Tan es así, que las "Reglas que deben observarse en los papeles periódicos...", dictadas en 1788, explícitamente prohíben que se desacredite a los teatros ${ }^{58}$. La solución que ofrecen las coplas de El teatro y los actores agraviados para reparar el agravio de los críticos modernos es recurrir a poetas que, emulando a los antiguos, puedan impugnar las críticas. La tonadilla se posiciona a favor de "los antiguos" en el debate de los antiguos y modernos, reservando el título de poetas para los antiguos, y el de escritores a secas para "los críticos" ${ }^{9}$. Por último, en las seguidillas finales Garrido acusa a "los críticos" de quijotismo, reiterando la creencia de que expresar una opinión públicamente era una práctica fútil en el mejor de los casos, nociva en el peor de ellos.

El teatro y los actores agraviados provocó una de las pocas respuestas a tonadillas específicas registradas en la prensa, en la forma de una carta anónima publicada en el Correo de los Ciegos en febrero de 178760. El autor de esta carta reclama el derecho de los críticos (a quienes llama "los escritores") a dictar los repertorios y prácticas teatrales, siempre con el fin de agradar al público y por encima de la opinión de actores y compositores. Como ocurrió en otras partes de Europa cuando la prensa periódica empezó a cobrar fuerza, existía en España la expectativa de que tanto prensa como teatro, en este caso, las tonadillas escénicas, estuvieran al servicio de los intereses del Estado ${ }^{61}$. El autor de la carta del Correo ve a los críticos como portavoces de la postura oficial, y se confiesa perplejo ante la renuencia de los actores-cantantes a enmendar los vicios denunciados por la crítica periodística $^{62}$. Más aún, interpela al compositor de la tonadilla (Esteve) por

\footnotetext{
58 "Reglas que deben observarse...", p. 150.

59 Que la tonadilla ve a "los críticos" como un fenómeno moderno queda patente en que los llama "esos escritores que han salido hoy" y "modernos, ilusos sabios".

${ }^{60}$ Correo de los Ciegos de Madrid, 20-2-1787, p. 156.

${ }^{61}$ Habermas observa que desde el siglo XVII los gobiernos trataron de utilizar la prensa para promover sus intereses. La transformación..., pp. 59-60.

62 "... los cómicos quieren defender sus extravagancias contra las justas críticas, que se les hacen en algunos papeles públicos, o por mejor decir, protestan subsistir en sus disparates, a pesar de cuanto digan los escritores". Correo de los Ciegos de Madrid, 20-2-1787, p. 156.
} 
escribir una obra "necia, sin moralidad y perjudicial", y lo califica de asalariado que busca adular a los actores. La falta de moralidad consiste, en este caso, en resistirse a la reforma del teatro auspiciada por el sector ilustrado como parte de la policía y el buen gobierno. La carta lamenta que "no se puedan observar en estos teatros corrompidos [los coliseos] las sabias reglas que se han establecido para el de la ópera", es decir, el de los Caños del Peral ${ }^{63}$.

Al insistir en que actores y compositores conformen sus prácticas al juicio de "los críticos", el autor de la carta del Correo favorece la idea, común en la ilustración tardía, de que la opinión pública no era el derecho de todos, sino de una clase privilegiada destinada a guiar a las masas ${ }^{64}$. Mientras que la tonadilla apela a las preferencias del público y a los derechos de los trabajadores del teatro, la carta invoca la normativa oficial dictada para los Caños y el buen juicio de los críticos, dando a entender que "agradar al público" no significa satisfacer la demanda, sino procurar un teatro musical orientado a la instrucción nacional. Para los tonadilleros, se ofende al público cuando no se toman en cuenta sus preferencias. Para "los críticos", se ofende al público cuando se le ofrece un entretenimiento destinado a "divertir a niños y gente idiota" 65 . El autor de la carta del Correo presupone que legisladores y escritores ("los inteligentes") poseen una superioridad intelectual y moral por encima de los actores, de los compositores y del pueblo mismo "obstinado en su barbarie". En consecuencia, exige que los teatros se sujeten a los dictámenes de la crítica periodística. El teatro y los actores agraviados rechaza dicho planteamiento y niega a la opinión impresa voz y voto en el teatro nacional, presentando a los actores, a los compositores y al pueblo como los únicos involucrados en el asunto.

Las decisiones concernientes a la práctica teatral preocupaban no solo a la clase letrada, sino también a una base popular que asistía asiduamente a los coliseos - los famosos chorizos y polacos, auténticos clubes de fans de las compañías de Martínez y Rivera, respectivamente-. A pesar de que esta base tenía poco acceso a los medios impresos, aparecían en los periódicos como interlocutores reales o imaginarios de las clases media y alta. A través de estas referencias participaban indirectamente de la discusión, y mucho más directamente con las opiniones que de viva voz se expresaban en los coliseos y que dieron lugar a más de una carta en la prensa. Una extensa "Carta sobre los teatros" publicada en el Diario de Madrid los días 5, 6, y 7 de abril de 1790 muestra cuánto proliferaban los debates sobre el teatro entre diferentes grupos sociales. El texto, firmado por D.M.R.F., afirma

\footnotetext{
63 Ibid.

${ }^{64}$ Habermas reconoce que la opinión pública en el siglo XVIII era elitista y que la prensa alcanzaba únicamente a los "estamentos ilustrados". La transformación..., p. 60.

65 Correo de los Ciegos de Madrid, 20-2-1787, p. 156.
} 
que "los Teatros de esta Corte hace tiempo que están sirviendo de asunto en casi todas las concurrencias", y a continuación divide a los interlocutores en tres grupos:

Tres clases de gentes son las que sostienen estas conversaciones. La primera, de los apasionados a determinadas personas de los actores: la segunda, apasionados y antagonistas de las cosas nacionales: y la tercera, que son los menos, de los indiferentes que discurren con imparcialidad. De la primera especie de personas, se forman unos partidos tan necios y opuestos entre sí, aun en los mismos teatros nacionales, que años hace se distinguen en Madrid sus apasionados con los nombres extravagantes de Chorizos y Polacos $[\ldots]^{66}$.

Desde luego estos apasionados del sexo masculino seguían a los actores, especialmente a las actrices, en buena parte por sus habilidades como cantantes, y ellas creaban la ilusión de que correspondían a su preferencia mencionándolos en las tonadillas. Dado que los chorizos y los polacos ocupaban el patio de los coliseos, mientras que las mujeres se sentaban en un área más alejada del escenario (la cazuela), se entiende que este sector popular de la opinión estaba formado casi exclusivamente por hombres. Esto no quiere decir que las mujeres no expresaran sus pareceres sobre el teatro, pero sí que no se les reconocía como sujetos de opinión ${ }^{67}$.

A pesar de lo que canta la tonadilla analizada, compositores como Laserna y Esteve eran conscientes del potencial de las tonadillas escénicas para influir en la opinión pública, equiparable a la función de la prensa en las últimas décadas del XVIII. Inclusive parece que Laserna consideraba las tonadillas "de crítica o sátira" un subgénero en sí, como queda expresado en una carta que escribió a la Junta de Reforma de Teatros en 1792. En ella, Laserna pide se le aumente el sueldo como compositor de los teatros de Madrid.Justifica su petición en parte explicando que las tonadillas para ese entonces requerían más labor:

[...] cuando formé la primera y aún segunda escritura para ejercer mi profesión en el Teatro, no se hallaba este en el estado que actualmente; las tonadillas eran de un corte del todo diferente, reduciéndose las a solo, aun mero cuento, las a dúo, a tres, y generales a una unión de caracteres jocosos, que formaban varios juguetillos músicos, cuya composición era de poco trabajo, careciendo casi todas de acción, y asunto; sustituүéronse después las de critica, o sátiva compuestas de introducción, coplas, y seguidillas las

${ }^{66}$ Diario de Madrid, n. ${ }^{\circ}$ 95, 5-4-1790, pp. 377-378.

${ }^{67}$ La exclusión de las mujeres ha sido también una crítica recurrente de la teoría de la esfera pública de Habermas, por autores como Geoff Eley. En el prólogo a la nueva edición alemana de La transformación estructural de la vida pública, Habermas mismo respondió a estas críticas, explicitando que "tanto a las mujeres como a los otros grupos [trabajadores, campesinos y el "populacho"] les fue negada la participación activa y con igualdad de derechos en la formación política de la voluntad y de la opinión". Sin embargo, el autor sostiene que el principio autotransformador de la esfera pública burguesa puede aplicarse a otros grupos sociales como las mujeres o los trabajadores. J. Habermas: La transformación..., p. 8. 
cuales se han ido desterrando, o por mejor decir se han desterrado ya totalmente, menos las de a solo cuya esterilidad de asunto no permite igual reforma $[\ldots]^{68}$.

De acuerdo con esta cita, para la década de 1790 las tonadillas satíricas grupales, como El teatro y los actores agraviados, caían ya en desuso, si bien las tonadillas a solo continuaban en esta línea debido a su formato, que no se prestaba a dramatizar una historia. Se podría establecer una hipótesis de relación de causalidad entre crítica periodística y tonadillas satíricas, según la cual las tonadillas habrían reaccionado al aumento de la prensa de opinión adoptando una función semejante. Sin embargo, es también concebible que el momento histórico que atravesaba España en las postrimerías del reinado de Carlos III contara con las condiciones necesarias para favorecer, simultáneamente en diversos medios, un ensayo más o menos consistente de lo que en el siglo XIX se consolidaría como opinión pública.

\section{Música y opinión pública en el Madrid del XVIII tardío}

Los debates que circularon en la prensa madrileña durante las dos últimas décadas del siglo XVIII se concentraron en temas específicos que preocupaban a la nación y que, por tanto, se convirtieron en los primeros asuntos de la opinión pública. Tal es el caso de las comparaciones entre la música española y la extranjera, relacionadas con las controversias sobre si la nación española debía ser cosmopolita o rechazar la influencia europea. La preocupación por un supuesto atraso de la música española formó asimismo parte de este debate. La discusión urgía, por un lado, la modernización de España para estar a la par con las prácticas musicales europeas, y por otro, la defensa de lo español frente a las tendencias extranjeras. Ambos lados del debate se aprecian en la serie de seis cartas del Diario de Madrid que versan sobre la ópera italiana en los Caños del Peral, y en las tonadillas que protestaban contra la crítica periodística por considerarla una moda europea que lastimaba al teatro nacional. Además de las críticas y reseñas, la prensa ofreció un espacio para la difusión del conocimiento musical. El Diario de Madrid publicó de vez en cuando artículos informativos sobre música, sobre todo cuando el repertorio presentado en los Caños del Peral propició la ocasión para educar al público en géneros como la ópera, el ballet pantomimo e incluso la sinfonía. Los primeros artículos informativos sobre música aparecieron justo antes y después de que se reabriera el teatro en 1787 para proporcionar datos sobre la ópera italiana y comunicar las reglas del nuevo teatro ${ }^{69}$.

\footnotetext{
68 "Papeles referentes a los teatros de Madrid", compilados por Francisco A. Barbieri. Biblioteca Nacional de España, MSS/14016/3, 65.

${ }^{69}$ Ver Juan Bautista Montaldi: "Algunas noticias instructivas sobre el drama llamado Ópera", Diario Curioso, Erudito, Económico y Comercial, n. ${ }^{\circ}$ 201, 17-1-1787, pp. 70-71.
} 
A través de la reseña teatral y musical y de la crítica literaria se verifican intentos por establecer en Madrid una publicidad literaria, que es para $\mathrm{Ha}-$ bermas precursora de la publicidad política ${ }^{70}$. $\mathrm{Al}$ menos en ciertos aspectos, el proceso español en el XVIII tardío se asemeja al descrito por Habermas como "temprana publicidad política" en Strukturwandel der Öffenlichtkeit (1961), según su análisis de los casos de Alemania, Inglaterra, y Francia ${ }^{71}$. Por tanto, resulta pertinente referirse a la obra de Habermas, teniendo siempre en mente que el constructo "opinión pública" como tal no aparece en ninguno de los textos considerados en este trabajo ${ }^{72}$. Las cartas y artículos en torno al teatro musical publicados en la prensa española pueden considerarse ensayos de un contacto comunicativo racional entre distintos miembros de la sociedad; un contacto racional que constituye, para Habermas, la base para la esfera pública ${ }^{73}$. De hecho, y como se aprecia en las cartas del Diario, las discusiones más acaloradas giraban en torno a qué constituía una opinión racional. Los esfuerzos por crear un lenguaje propio de la opinión impresa encontraron gran resistencia, reflejada en el cliché del "lenguaje oscuro" o "jerga" del que se acusaba a la prensa. Ciertamente, como apunta Inmaculada Urzainqui, la prensa y la crítica en tanto que "nuevos instrumentos culturales" en la España de Carlos III "tenía[n] que... conquistar su propio espacio" epistemológico, lo cual significa que quedaban por definirse sus formatos, alcances y reglas en el contexto de la sociedad española ${ }^{74}$.

El público lector que se consolidó en las dos últimas décadas del XVIII también formaba parte del público teatral. Cuando algunos de los asistentes a los teatros empezaron a fungir además como críticos, el concepto de público cambió. Si bien los habitantes de Madrid discutían y opinaban sobre el teatro antes de este periodo, el poner esas opiniones por escrito

70 "La publicidad política resulta de la publicidad literaria; media, a través de la opinión pública, entre el Estado y las necesidades de la sociedad". J. Habermas: La transformación..., p. 68.

${ }^{71}$ Esta temprana publicidad política prevalece, según el autor, hasta mediados del siglo diecinueve. Ibid., 10 .

72 Cuando aparece la frase "opinión pública" en la prensa de las décadas de 1770 y 1780 , con frecuencia se refiere a la vox populi. Como notable excepción puede mencionarse la referencia a la opinión pública en contraposición a la ley en el "Discurso 75" de El Censor, uno de los dedicados a la utopía del país de los Ayparchontes. El Censor, n. ${ }^{\circ}$ 75, 20 de octubre 1785, p. 138. De acuerdo con Glendinning, el constructo "opinión pública" en el sentido habermasiano empezó a aparecer en la prensa en 18081809, coincidiendo con la Guerra de Independencia. Como ejemplo presenta el prospecto del Semanario Patriótico editado por Eugenio de Tapia y Manuel Quintana. Nigel Glendinning: "Cambios en el concepto de opinión pública a finales del siglo XVIII”, Nueva Revista de Filología Hispánica, 33, n. 1, 1984, pp. 158-159.

${ }^{73}$ Ver las secciones "Instituciones de la publicidad" y "La relación de la publicidad literaria con la publicidad política", J. Habermas: La transformación..., pp. 69-80 y 88-93.

${ }^{74}$ Inmaculada Urzainqui: "La crítica literaria en la prensa del siglo XVIII: elementos de su discurso teórico", Bulletin Hispanique, n. ${ }^{\circ}$ 102, 2, 2000, p. 525. También I. Urzainqui: "Un nuevo instrumento cultural: la prensa periódica", La República de las Letras en el siglo XVIII, Joaquín Álvarez Barrientos, François López, Inmaculada Urzainqui (eds.), Madrid, CSIC, 1995, pp. 125-216. 
provocó nuevas respuestas por parte de los administradores, compositores y actores. La creciente presencia de la prensa periódica en la sociedad española interpeló a aquellos géneros artísticos que, como las tonadillas, se vieron envueltos en este nuevo tráfico de opiniones y críticas aun cuando pretendieran quedar fuera de la modernidad. Las tonadillas escénicas "a solo" establecían un diálogo con los espectadores, sobre todo con el público masculino del patio de los coliseos. Sin embargo, los autores de cartas en la prensa probablemente ocupaban los palcos ${ }^{75}$. Las dos tonadillas estudiadas en este trabajo trataron de separar el público presencial (equiparable al público plebeyo de Habermas ${ }^{76}$ ) del público literario (equiparable al público burgés), caricaturizando a la prensa y a la crítica periodística como una moda extranjera, enemiga del público presencial que era leal al teatro español. Al igual que ocurrió en otras naciones europeas, el sector ilustrado consideró sujeto de opinión únicamente a la elite. En palabras de Habermas, a este sector ilustrado pertenecen "los sabios" 77 , denostados en las tonadillas de Laserna y Esteve como "sabios modernos". A primera vista, parecería que la retórica xenófoba de las tonadillas y de muchos textos impresos, incluidos panfletos, libros y cartas a la prensa, se contrapone con la noción de una opinión pública moderna. No obstante, el mismo hecho de que algunas tonadillas respondieran directamente al fenómeno de la prensa y a los críticos demuestra que la idea del público empezaba a transformarse ${ }^{78}$.

Sin embargo, en otros aspectos el proceso español presenta condiciones únicas que divergen de la formulación propuesta por Habermas. Para el filósofo alemán la constitución de una esfera pública separada del Estado y capaz de confrontarlo se encuentra indisolublemente ligada al estrato burgués formado por funcionarios estatales y propietarios del capital como comerciantes, banqueros, editores y manufactureros. La publicidad habermasiana se alcanza cuando la sociedad burguesa logra que sus intereses se vuelvan públicos y sean adoptados por los súbditos como distintos a los in-

\footnotetext{
75 Este sector se asemeja un poco al público temprano que Habermas ubica en el París del siglo XVII. Sin embargo, este público temprano se encontraba ligado a la publicidad representativa de la corte de Luis XIV, cosa que no sucedió en Madrid a finales del XVIII porque el espectáculo teatral tenía lugar en los teatros públicos, y el rey rara vez asistía. "Le public se llamaba en la Francia del siglo XVII a los lecteurs, spectateurs, auditeurs, en su calidad de destinatarios, consumidores y críticos de arte y literatura; se entendía todavía por ello, en primer lugar, a la corte, y luego también a la parte de la aristocracia urbana que, junto a una rala capa superficial de la burguesía, tenía asiento en los palcos del teatro de París". Habermas: La transformación, p. 69.

${ }^{76}$ Ibid., p. 76.

77 Ibid., p. 63.

78 Para Love, pareceres encontrados y aun contradictorios acerca de la música señalan que sus autores se sentían miembros del público musical: "El argumento, que tiene origen en la defensa razonada del gusto personal, se encuentra en el núcleo de la experiencia de ser parte del público musical, el cual, lejos de ser una comunidad discursiva unificada, era en cambio una coalición díscola de puntos de vista e intereses dispersos y rivales". H. Love: "How Music...", p. 267.
} 
tereses de la autoridad. La prensa funciona como vehículo de este proceso, porque si bien la autoridad pretende usarla para promover sus intereses, los ciudadanos toman la información publicada y la reviran contra la autori$\mathrm{dad}^{79}$. Este modelo se aplica bien a las ciudades y territorios independientes alemanes, en los que tanto ciudadanos como Iglesia contaban con estructuras más o menos autónomas, pero no tanto a un estado absoluto en el que gobierno y religión seguían centralizados ${ }^{80}$. Aunque es cierto que las clases medias y altas madrileñas que asistían a los teatros y escribían o leían la prensa pueden concebirse como una burguesía cultural, en el sentido de que no predominaban los nobles, la relación de esta incipiente burguesía con el capitalismo difiere del caso alemán analizado por Habermas ${ }^{81}$. Aún más, esta potencial burguesía cultural no se constituyó con base en la oposición o crítica del Estado, unos acaso por temor a la censura, otros porque se beneficiaban del régimen absolutista y preferían mantener el status quo. Es decir, ni el teatro musical ni la crítica u opinión se constituyeron como una entidad cuya función definidora fuera pedir cuentas al gobierno, al menos no durante esta etapa.

A pesar de que durante la década de 1780 y principios de la de 1790 buena parte de la opinión impresa se abstuvo de confrontar al poder absoluto, puede afirmarse que tuvo una función política en tanto que permitió a muchos españoles imaginar y bosquejar la nación moderna. Además de la prensa, la actividad musical proveyó también un locus para digerir los cambios originados por la modernidad ilustrada, entre los cuales se cuenta la reapertura del Teatro de los Caños del Peral. Los proyectos de tendencia cosmopolita como los Caños del Peral, así como la opinión impresa que los apoyaba, se tornaron menos viables a partir de la Revolución francesa. Después de la prohibición de los periódicos en 1791, la prensa hubo de buscar nuevos caminos para servir de vehículo a la opinión pública.

Estudiar el impacto del teatro musical en la opinión pública española requiere tomar en cuenta que los coliseos de Madrid presentaban ciertas características distintas de muchos teatros en Europa, porque dependían de la Junta de Hospitales y de las autoridades locales, en vez de hacerlo de los empresarios privados o de la corte. Asimismo, un análisis más profundo de los límites del modelo habermasiano requiere considerar los procesos económicos

\footnotetext{
79 J. Habermas: La transformación..., p. 69.

${ }^{80}$ Habermas pone como ejemplo las "sociedades alemanas" en las que burgueses y nobles se reunían como "meros" hombres al margen del ámbito del absolutismo y en secreto. Ibid, p. 73. El tipo de esfera pública que Habermas propone para el estado absoluto se inspira en la corte de Luis XIV, en la cual la mera presencia del monarca generaba el espacio público. Es decir, la persona del rey representaba lo público. "Acerca del tipo de publicidad representativa", ibid., pp. 44-51.

${ }^{81}$ Difiere también en lo que respecta a la demarcación entre lo privado, ligado a la vida doméstica de la familia nuclear, y lo público, separación esencial dentro del modelo habermasiano.
} 
en el ocaso del Imperio español, para elucidar sus conexiones con los culturales. Sin pretender agotar los debates en torno a la música y el teatro musical, los ejemplos provistos indican que ambas actividades artísticas formaron parte importante de la génesis de la opinión pública moderna a finales del siglo XVIII, sobre todo si se repara en que muy frecuentemente llevaron a la discusión de asuntos indispensables para una sociedad moderna, como lo eran la educación y los roles de género. Ciertamente, el paradigma de $\mathrm{Ha}$ bermas ilumina aspectos del caso español, pero no lo abarca en su totalidad. La vida musical del momento revela detalles de la formación de la opinión pública que permiten comprender mejor el proceso de desarrollo de la modernidad española y su posición en la historia de la modernidad europea.

Apéndice 1. Letra de la tonadilla El Diario. Blas de Laserna, 1787.

\section{Introducción}

Un diario muy nuevo quiero presentar

y cosas extrañas en él se verán.

Tiene ventas, tiene hallazgos,

tiene asuntos literarios,

todo tiene en conclusión,

pero solo se dirige

a enmendar el fiero horror.

En él se refiere y se da a notar

mil cosas que algunos no comprenderán.

Los defectos bien se entienden

y deseo que se enmienden

para lograr mi intención.

Y así, queridos del alma,

prestadme vuestra atención.

Del diario será el premio y muy justa recompensa

que aquel que en el daño piensa deje de pensar el mal.

De esta manera la idea que lleva mi pensamiento

sin un remedio violento a efectuarse llegará.

\section{Coplas}

1. (Literatura) Por un escritor de moda

se imprime un librito nuevo

que contiene doce ciencias

y puede ir por el correo.

Los sabios modernos

que acudan a suscribirse

perderán tiempo y dinero. 
2. (Pérdidas) Se perdió un perro de lanas y aquel que lo haya encontrado dos mil reales de dinero da una señora de hallazgo. Acuda al diario; si se le perdiera un hijo, tal vez no diera otro tanto.

3. (Hallazgos) A la hora de la retreta se ha encontrado un currutaco siguiendo el pobre infelice a una niña de quince años. Quien quiera buscarlo acuda a Antón Martín, que le darán sin hallazgo.

Allegretto

El que criticar quiera

la maldad fea

sobre cualquier asunto motivo encuentra.

Así prosigo, pues deben criticarse siempre los vicios.

4. (Ventas) Un reloj de oro muy bueno vende un infeliz indiano que de cuarenta mil pesos una niña le ha dejado.

Quien quiera comprarlo le restituirá el cariño mientras que duren los cuartos.

5. (Nodrizas) Una burra busca cría con leche de cuatro meses, dentro o fuera de su casa si es que alguno la quisiere. Bien claro se advierte, para un niño mayorazgo mejor ama no se puede.

6. (Alquileres) Se alquila en un tercer piso sala y alcoba pequeñas con dos mesas y tres sillas y sin ninguna asistencia. Aquel que la quiera, pagará según costumbre más que por la casa entera. 


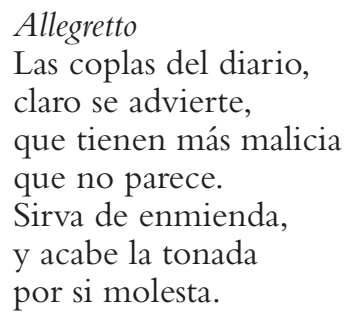

Final

Y solamente espero, si acaso os ha gustado, dejéis recompensado con vuestro fino aplauso mi afecto y humildad.

Concededla benignos, y atentos y amorosos, finos y cariñosos, mis anhelos benignos sabed recompensar.

Apéndice 2. Letra de la tonadilla El teatro y los actores agraviados. Pablo Esteve, 1787. Introducción

[Sale Garrido con diarios, censores y papeles en la mano]

De cuantos papelotes hoy los críticos sacan todos sobre los teatros, todos descargan

Actores y comedias los muerden y los rajan, y todo se critica con furia y rabia

Paciencia, Garrido, más paciencia no, más paciencia no, que callar no quiero a tanto baldón

Teman mi venganza, teman mi furor esos escritores que han salido hoy. 
[Los tres]

Críticos satíricos

que sin compasión

a todos ultraja su murmuración.

[Sale mujer]

Ay Garrido, que vengo

furiosa y sofocada

de ver que unos pedantes

tan mal nos tratan.

[Sale Alfonso]

Consuela mi tormento,

Garrido de mi alma,

porque yo he de perderme

con lo que pasa.

[Garrido]

Amigos, paciencia,

más paciencia no,

más paciencia no

y decidme claro

qué tenéis los dos.

\section{[Mujer]}

Teman mi venganza, teman mi furor

esos escritores

que han salido hoy.

[Los tres]

Críticos satíricos

que sin compasión

a todos ultraja su murmuración.

Allegretto

[Mujer]

Tal turba de censores

se han [sic] levantado

que a sátiras destruyen

nuestros teatros.

[Garrido]

Más que celo es industria

sus papelotes,

para sacar los cuartos

a los lectores. 


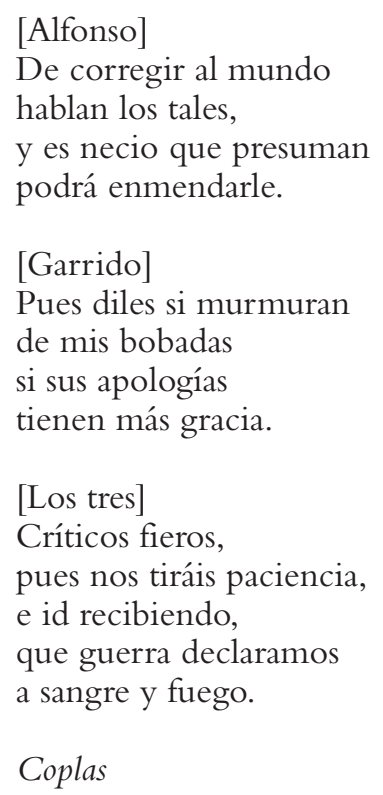

1. [Alfonso]

Los periódicos papeles

nos desacreditan tanto

que al fin vendremos a ser

de las gentes el escarnio.

[Garrido]

Déjate de boberías, reírnos y despreciarlos, que lo que más nos importa es el ganar muchos cuartos.

2. [Mujer]

Los eruditos intrusos

de discretos blasonando

se burlan de las comedias

que al pueblo representamos.

\section{[Garrido]}

Pues que escriban ellos unas

y veremos en el teatro

si sus obras son mejores

que las que están censurando.

[Los tres]

Mas chito, chitito, 


\author{
que pueden oír \\ los sabios sujetos \\ critica-defectos, \\ que sus malos picos \\ tratan de borricos \\ a los de Madrid. \\ Qué bobos, qué necios, \\ cosa es de reír \\ Con capa de sabios \\ agravan a varios \\ y cuanto en sus obras \\ satíricas, tontas, \\ hay que corregir.
}

3. [Alfonso]

Se ríen de que en las magias

nos ven si invisible [sic] estamos

y critican que bailemos

con los disfraces de diablo.

\title{
[Garrido]
}

Caso de esas boberías

no hace el verdadero sabio,

que esta diversión se pone

para necios y muchachos.

4. [Mujer]

Ningún hombre de talento

hace de sus dichos caso,

que es mejor buitre que alaba

que cisne vituperando.

\section{[Garrido]}

Si los poetas antiguos

se vieran tan difamados,

a sus críticas y a ellos

los comieran a bocados.

[Los tres]

Mas chito, chitito,

que oyendo estarán

Busquemos poetas,

que sus agudezas

pues a ellos les cortan

también bien la lana,

nos defenderán. 
Corramos, marchemos

a desagraviar

las impugnaciones

de estos escritores

y con seguidillas

esto acabará.

\section{Seguidillas}

[Nicolasa]

En un siglo, señores,

tan ilustrado,

no es mucho que pretendan

ser sabios tantos.

[Alfonso]

Hay muchos escritores

carteles atisbando,

que andan con el anteojo

noticias rebuscando.

[Garrido]

Esos [haced] cuenta

que son unos traperos

a la violeta.

[Nicolasa]

En fin, estos modernos

necios, ilusos, sabios,

son los antagonistas

de nuestros pobres teatros.

[Garrido]

Quijotes nuevos,

que han tomado a su cargo

deshacer tuertos.

[Nicolasa]

$\mathrm{Y}$ aquí los tres postrados, nobles señores.

[Los tres]

Nos defendáis, pedimos,

de criticones.

Y logre la tonada

vuestros favores. 